RESPONSE

\title{
Discerning the "Stumbling Block"
}

Philip A. Cunningham, Institute for Jewish-Catholic Relations of Saint Joseph's University, Philadelphia

A Response to Cardinal Kurt Koch's October 30, 2011 Keynote Address at Seton Hall University during the $10^{\text {th }}$ Annual Meeting of the Council of Centers on Christian-Jewish Relations

\section{Introduction}

Cardinal Kurt Koch's combined keynote address at the 10th annual meeting of the Council of Centers on Jewish-Christian Relations (CCJR) and the 18th Annual Msgr. John M. Oesterreicher Memorial Lecture, delivered at Seton Hall University on October 30, 2011, is quite important for a number of reasons. In addition to being the first major English address by the new president of the Pontifical Commission for Religious Relations with the Jews, it can also be seen as providing a panoramic snapshot of the "state-of-the-question" from the Vatican's perspective regarding several important topics in Catholic-Jewish relations. Furthermore, Cardinal Koch's remarks, "Theological Questions and Perspectives in Jewish-Catholic Dialogue," vividly demonstrate how far relations between the two communities have come in the nearly fifty years since Nostra Aetate. We are grappling with subjects that a half-century ago could scarcely have been imagined as even possible to discuss.

I am indeed grateful for the cardinal's very thoughtful presentation and his welcome of this symposium in Studies in Christian-Jewish Relations as an opportunity to share ideas about complex, sensitive, and in many ways unprecedented questions. As his predecessor Cardinal Walter Kasper stated on more than one occasion, "Nostra Aetate was of course only the beginning of a new beginning. We are only at the start of a new start of a 'Christian Theology of Judaism'... Many decisive questions still remain open."1 Therefore, Cardinal Koch's address offers a major stimulus for deepening the interreligious conversation as we Christians and Jews consider what he calls "the theological questions....in the forefront of Jewish-Christian dialogue." I am also glad that the cardinal's remarks occasionally correct some unfortunate efforts in the past decade to weaken the impact of Nostra Aetate.

I would like first to mention some ideas the cardinal expresses that strike me as particularly insightful and noteworthy. This will be followed by a few observations for future conversation. In the context of this symposium, I do so as a fellow Catholic might chat with an academic colleague down the hall about matters that deeply concern us both.

\section{Some Significant Statements}

In the first part of Cardinal Koch's address about the "complex history between Christians and Jews," he speaks movingly about the Shoah. After distinguishing between "godless,

\footnotetext{
1 "The Relationship of the Old and the New Covenant as One of the Central Issues in Jewish-Christian Dialogue," Centre for the Study of Jewish-Christian Relations, Cambridge, U.K., December 06, 2004.
} 
anti-Christian and neo-pagan" Nazism, he goes on to declare that "we Christians nevertheless have every cause to remember our complicity in the horrific developments, and above all to confess that Christian resistance to the boundless inhuman brutality of ideologically-based National Socialist racism did not display that vigour and clarity which one should by rights have expected." He acknowledges that "a Christian theological anti-Judaism had [fostered] a widespread anti-Semitic apathy against the Jews [and] was embedded in the furrows of the souls of not a few Christians." In what to me was an interesting new insight, he further comments that "[w]ith shame we Christians must also acknowledge that Hitler, with his joint rejection of both Judaism and Christianity, had grasped the true essence of Christianity and its intrinsic relationship with Judaism better than not a few Christians themselves."

Likewise very telling is his statement that "We Christians must therefore honestly deplore the fact that only the unprecedented atrocity of the Shoah was able to effect a real turning point in thinking," which at the Second Vatican Council "enabled a fundamental new beginning in the relationship between Jews and Christians" [emphasis added]. In the past decade some prominent Catholics have engaged in what appeared to me to be a minimization of Nostra Aetate. ${ }^{2}$ Cardinal Koch's forthright recognition that an "epoch-making new course [was] set by the Council" seems to me to be utterly crucial if there is to be no future "recurrence of the dangerous estrangement between Christians and Jews" or if "the regained understanding of the Jewish roots of Christianity [is not to] lapse once more into oblivion."

I also very much appreciate the cardinal's warning against the dangers of Marcionism and antiJudaism among "traditionalists" to the right and also "on the liberal side" to the left. The reform in Catholic teaching regarding Jews and Judaism is a great centrist movement in the church, and is not primarily the domain of either the left or the right, both of which can and have gone to one extreme or the other.

In the second and largest section of his address on the "Unity and difference between Judaism and Christianity," Cardinal Koch makes another very welcome caution about the danger of reducing the relationship between Judaism and Christianity "to the level of merely another variant of inter-religious conversation, so that its irreducible uniqueness is no longer brought to bear." Recalling Pope John Paul Il's words about Judaism being "intrinsic" to Christianity, the cardinal clearly wants to stress the uniqueness of Christian-Jewish relations among all the other bilateral interreligious relationships in the world. In this perspective, it is therefore quite appropriate that the Commission for Religious Relations with the Jews that Cardinal Koch directs falls under the aegis of the Pontifical Council for Promoting Christian Unity and not under the Pontifical Council for Interreligious Dialogue. This Vatican organizational structure does not mean to suggest that Judaism is a subset of Christianity, but that the church sees its organic rapport with the Jewish tradition and people as in a different category from its connections with all other religious heritages in the world.

This distinctiveness is also evident in Cardinal Koch's formulation that the New Testament is not a substitute for the Old Testament. He notes, citing Pope Benedict XVI, that there were "two new ways of reading the Old Testament after the year 70, namely the Christological exegesis of the Christians and the rabbinical exegesis of that form of Judaism which arose after the destruction of the temple." Setting aside the fact that the Christian Old Testament and the Jewish Tanakh are not identical in content and arrangement, the cardinal very significantly observes that, "Since

\footnotetext{
${ }^{2}$ See my "Official Ecclesial Documents to Implement the Second Vatican Council on Relations with Jews: 'Study Them, Become Immersed in Them, and Put Them into Practice,"' Studies in Christian-Jewish Relations 4/1 (2009) at: http://ejournals.bc.edu/ojs/index.php/scjr/article/view/1521/1374
} 
both modes each involved a new interpretation of the Old Testament, the crucial new question must be precisely how these two modes are related to one another. But since the Christian church and post-biblical rabbinical and Talmudic Judaism, which originated only after the destruction of the temple, developed in parallel, this question cannot be answered from the New Testament alone." How the "two modes are related to one another" is not a question the New Testament authors could address inasmuch as neither a Christianity-distinct-from-Judaism nor a normative rabbinic Judaism yet existed. If Christians today "want to rightly understand the will and word of God," as Cardinal Koch quotes Pope Benedict, "After centuries of opposing positions we recognise it as our duty that these two ways-Christian and Jewish-of reading the Biblical writings must enter into dialogue with one another..."

Implicitly, though quite clearly, this impetus to discern together God's will presupposes that both Christians and Jews see something of value in each other's traditions. From a Christian perspective, this involves our contemporary recognition that God's covenantal bond with the Jewish people did not end with the destruction of the Jerusalem Temple, but continued through the rise of rabbinic and post-rabbinic Judaism down to the present day. In my experience, some Catholics do not take seriously the 1974 injunction of the Commission that Cardinal Koch now heads to "strive to learn by what essential traits Jews define themselves in the light of their own religious experience," ${ }^{3}$ an axiom echoed repeatedly by Pope John Paul II. ${ }^{4}$ The need affirmed by Cardinal Koch for dialogue between Christian and Jewish traditions of biblical interpretation certainly honors the principle of learning from Jewish self-understanding.

The cardinal's nuanced discussion of the "so-called mission to the Jews" is also significant. He observes that: (1) The "universal salvific significance of Jesus Christ and consequently the universal mission of the church are of fundamental significance; (2) The church's evangelical task vis-à-vis Jews occurs "in a different manner from that to the nations;" (3) The Catholic church "neither has nor supports any specific institutional [conversionary] mission work directed towards Jews;" and (4) "The rejection of an institutional mission to the Jews does not...exclude Christians from bearing witness to their faith in Jesus Christ also to Jews, but [they] should do so in a humble and unassuming manner" [emphasis added]. The phrase "bearing witness" in Catholic parlance refers to the explanation of Christian faith in the interest of fostering mutual understanding in service of the Age to Come, but without intending to convert the other. Since Cardinal Koch had earlier spoken of the necessity for intense dialogue between Christians and Jews, his points here could perhaps be summarized as: the mission of the church toward Jews is one of dialogue and witness. This recalls John Paul II's statement very early in his papacy-almost charting its future course-that "we recognize with utmost clarity that the path along which we should proceed with the Jewish religious community is one of fraternal dialogue and fruitful collaboration."

The cardinal's remarks here are directly relevant to a controversy that occurred in the United States in the summer of 2009. A statement issued by two offices of the United States Conference of Catholic Bishops said: "Though Christian participation in interreligious dialogue would not normally include an explicit invitation to baptism and entrance into the Church, the Christian dialogue partner is always giving witness to the following of Christ, to which all are implicitly

\footnotetext{
${ }^{3}$ Pontifical Commission for Religious Relations with the Jews, "Guidelines and Suggestions for Implementing the Conciliar Declaration Nostra Aetate, No. 4" (1974), Preamble.

4 "Address to Representatives of Jewish Organizations at the Vatican," March 12, 1979; "Address to the German Jewish Community at Mainz," Nov. 17, 1980; "Address to the American Jewish Community in Miami," Sept. $11,1987$.

5 "Address to Representatives of Jewish Organizations," March 12, 1979.
} 
invited." This blurring of the crucial distinction between the "proclamation" of the Gospel in order to encourage baptism and the "witness" to Christian faith in the context of interreligious dialogue, both of which are evangelical activities, alarmed Catholics and Jews alike. It not only appeared that Catholics engaged in dialogue with Jews should always hope for their conversion (thereby compromising their ability to learn from Judaism), but perhaps they occasionally would explicitly invite their interlocutors to seek baptism. In response to a unanimous letter from all the Jewish movements and major civic agencies in the United States that Jews could not continue to converse with Catholics with such an understanding, USCCB leaders ordered the deletion of the murky sentence. Cardinal Koch's comments on both dialogue and conversionary missions in relation to Jews helpfully set the record straight about Catholic teaching on these matters. Following the Second Vatican Council the church has continuously institutionally encouraged interreligious dialogue with Jews and, indeed sponsors a number of formal, institutional dialogues with Jewish leaders through the Commission for Religious Relations with the Jews. The church also does not have any "institutional mission work directed towards Jews" to convert them. Logically, these two facts are congruent because in the activity of interreligious dialogue, Catholics are "bearing witness," not missionizing.

\section{Some Questions for Future Discussion}

Turning now to reflections stimulated by the cardinal's address, I would like to begin with his discussion that Jews and Christians are "One people of God, not two peoples of God." When I first read this phrasing, I thought of a similar expression in the 1985 Commission "Notes," which in reference to the eschaton spoke in the singular of "the people of God of the Old and the New Testament...tending towards a like end in the future: the coming or return of the Messiah-even if they start from two different points of view."7

It may well be that most Jews would be quite unhappy-for historical, demographic, and theological reasons-with the idea of a common peoplehood with Christians. But from a Catholic perspective, with its organic understanding of an intrinsic relationship with Judaism, the use of "one people of God" language makes sense. For Christians to see Jews as totally a separate peoplehood would risk slipping into the Marcionism that the church rejected long ago. Jews and Catholics can certainly agree to disagree about this phrasing, but still, as Cardinal Koch puts it, "live in mutual respect for one another."

I also wonder about the relationship among the concepts of: (1) Jews and Christians as one people, (2) who are in "one history of God's covenant" and (3) their different "modes" of actualizing the Tanakh/Old Testament as mentioned above. Cardinal Koch writes, "Speaking of the one people of God however proves to be difficult because this single people of God lives in separated communities. It may therefore be most appropriate in regard to Israel and the church to speak of the one people of God's covenant, which however lives in two parts in a state of division." My question is: if we can speak of two "modes" of interpreting the scriptures from ancient Israel, why can we not also speak of one people who both are covenanting with God but in different "modes"? Or alternatively, of one people of God in one history of God's covenant, whose covenanting with God occurs in two "modes"?

\footnotetext{
${ }^{6}$ Committees on Doctrine and Ecumenical and Interreligious Affairs, USCCB, "A Note on Ambiguities Contained in 'Reflections on Covenant and Mission,'” June 18, 2009, §7.

7 Pontifical Commission for Religious Relations with the Jews, "Notes on the Correct Way to Present Jews and Judaism in Preaching and Catechesis in the Roman Catholic Church" (1985), II, 10.
} 
Another question concerns the language of "fulfillment." Cardinal Koch quite rightly stresses that the New Testament has not superseded the Old Testament, insists that the New Covenant is "neither the annulment nor the replacement of the Old Covenant," and rejects the notion that "Israel as the historical people is no longer a theological, 'soteriological' entity." In each case he contrasts the unacceptable ideas of replacement, substitution, annulment, or obsolescence with "fulfillment." Thus, the Old Covenant and the New Covenant "stand with each other in a relationship of promise or anticipation and fulfillment," or as he writes elsewhere, "the incarnation of God in Jesus of Nazareth is to be understood as the culmination point and fulfillment of the selfrevealing God of Holy Scripture who turns towards the world..."

My question about this relates fulfillment with eschatology. Most, if not all, post-Nostra Aetate Catholic documents concerning Jews and Judaism feature a futurist eschatology. They stress Christianity's unfinished aspect, as when Christians daily pray in the Lord's Prayer "thy Kingdom come." Perhaps this is because a realized Christian eschatology, stressing what has already been accomplished in Christ, tends to overlook post-New Testament Jewish existence. ${ }^{8}$ A futurist eschatology, on the other hand, fosters a respect for Judaism's ongoing religious history. Thus, the Commission's 1985 "Notes" observes that the church, "realized already in Christ, yet awaits its definitive perfecting as the Body of Christ."

It seems to me that "fulfillment" is virtually always conceived in terms of linear time. Therefore, it unavoidably carries the connotation of something anticipated in the past now having been accomplished. Or to put it another way, if most Christians are used to thinking of "fulfillment" only in reference to a distant past (the Old Testament) that was fulfilled in the more recent past (the New Testament), how will they be able to conceive of the unfulfilled present (of Jews and Christians) pointing to God's promises in the future? If the Catholic Church understands itself with Jews as in a "pilgrim fellowship of the hopeful" into the eschatological future, then there is a danger that fulfillment language can mask the "unfinished" dimension of Christianity while simultaneously implying that Judaism is "finished." Does fulfillment language compromise the essential tension between the "already" and the "not yet" that is characteristic of Christianity and of Judaism, too, albeit in different ratios?

The futurist perspective is certainly evident in such New Testament texts as Rom 8:21 ("creation waits with eager longing for the revealing of the children of God") and Acts 3:21 ("[Jesus] must remain in heaven until the time of universal restoration that God announced long ago through his holy prophets"). Therefore, how does the church "as it makes its pilgrim way in hope" 10 affirm its future expectations even while asserting what has already occurred?

If "fulfillment" is problematic, ${ }^{11}$ perhaps it is better to use the language of "confirmation." This is in line with Paul's description of Christ as the "Yes" and "Amen" of all God's promises (2 Cor 1:20),

${ }^{8}$ This point relates to memorable sentences in the Pontifical Biblical Commission's The Jewish People and Their Sacred Scriptures in the Christian Bible (2001): "Accordingly, excessive insistence, characteristic of a certain apologetic, on the probative value attributable to the fulfillment of prophecy must be discarded. This insistence has contributed to harsh judgments by Christians of Jews and their reading of the Old Testament: the more reference to Christ is found in Old Testament texts, the more the incredulity of the Jews is considered inexcusable and obstinate" [II,A,5- $§ 21]$.

${ }^{9}$ PCRRJ, "Notes" (1985), II, 8.

${ }^{10}$ Second Vatican Council, Unitatis Redintegratio, 2.

${ }^{11}$ I note parenthetically that even Matthew's explicit fulfillment language is not simple prediction/ accomplishment. For instance, his actualization of Hosea 11:1 ("out of Egypt I have called my son"-an Exodus reference) does not understand the prophet as predicting the future but as remembering a past that is now being reprised. Thus the 
as Cardinal Koch noted. Thus, the New Testament confirms the Old Testament, the New Covenant confirms the Old Covenant, and the covenanting Christian people confirm the covenanting Jewish people.

I will leave this discussion of fulfillment with the hopefully thought-provoking suggestion that understanding fulfillment as confirmation also has implications for how we Christians view the eschatological future. If as Pontifical Biblical Commission declared, "Jewish messianic expectation is not in vain" 12 then it seems reasonable to expect that both Jewish and Christian messianic hopes will be confirmed on that Day beyond days - not in some supersessionist zero sum calculus, but in the realization of all the aspirations of both co-covenanting communities.

Finally, I'd like to offer several thoughts about the paragraph in Cardinal Koch's address that I found most stimulating. It concerns "the real stumbling block between Christianity and Judaism."

When one reviews the fundamental commonalities and the equally elementary differences between Judaism and Christianity, it becomes clear that both faith communities perceive Jesus of Nazareth as a figure thoroughly rooted in the Judaism of his time, but that the Christian confession that the one God of Israel has definitively revealed himself and shown his true face in Jesus of Nazareth stands between them, as the detailed conversation between Pope Benedict XVI and Rabbi Jacob Neusner in the first volume of his book on Jesus vividly demonstrated. They are indeed able to reach agreement on the fact that the earthly Jesus claimed divine authority for himself, and in that they contradict prominent trends in historical-critical exegesis which explain the New Testament confession of Christ as a product of the post-Easter community, and thus make Jesus appear simply as a misunderstood Jewish rabbi. If one follows such tendencies to their logical conclusion, the real stumbling block between Christianity and Judaism would be disposed of, and the motivation which makes Jewish-Christian dialogue necessary would also be eliminated. The dialogue between Pope Benedict XVI and Rabbi Neusner vividly draws attention to this predicament.

For myself, I discern the "stumbling block" differently and so do not see the "predicament" to which the cardinal alludes in the same way.

Thus, I wonder about the repercussions of the phrase "the earthly Jesus claimed divine authority for himself," especially when contrasted with the contemporary exegetical consensus about this. I realize that I am broaching a vast topic with many corollary issues that neither these brief reflections nor Cardinal Koch's wide-ranging address could adequately engage. Let me also stress that I am not at all implying that the cardinal endorses any of the problematic implications that I discuss below. In fact, I am quite sure that the opposite is true. But I am concerned that indistinct suggestions about seeing "post-Easter confessions of Christ" as also at work pre-resurrectionally could be highly problematic.

To begin, I need to describe how the majority of exegetes would comprehend the phrase "claimed divine authority for himself" because Cardinal Koch seems to prefer something different. It could be understood to mean that during his ministry Jesus acted and spoke as certain

Matthean Jesus recalls or affirms God's recurring covenantal life with Israel, something that reechoes down to the present day and beyond.

12 Pontifical Biblical Commission, "The Jewish People and Their Sacred Scriptures in the Christian Bible" (2001), II,A,5 - §21. 
that he was acting and speaking on behalf of God. He had the authority of a spokesperson for the divine. As David P. Efroymson has put it:

He claimed to know what God was doing-what he was up to-in the history of Israel: God has now, Jesus said, initiated his Reign and his claim upon Israel. He claimed to know the will of God: that God now demanded more of Israel; that God wanted healing done, even on the Sabbath; that God wanted following Jesus to take precedence even over the obligation to bury a parent. He claimed to know whom God wanted in the Kingdom, and under what conditions, at least now in a situation which Jesus construed as an emergency. He thus claimed to speak for God, and, at least in his summons to Israel and his initiative toward sinners, to act for God. This was a massive claim. ${ }^{13}$

As someone thinking he could speak for God, Jesus was functioning as a prophet. But Jesus seems to have gone beyond this: there is a widespread consensus among exegetes that Jesus acted, and presumably saw himself as, the climactic eschatological prophet, one who would herald and trigger the in-breaking of the Age to Come.

After exhaustively examining Jesus' halakhic teaching, John P. Meier partially summarizes the picture in a way that many, if not most, exegetes would support:

Jesus was, if nothing else, a charismatic religious leader, specifically a charismatic prophet. ...[I]t is the very nature of a charismatic religious leader to claim to derive his or her authority not from traditional channels (e.g., law, custom, ordination, election, hereditary succession, seniority, lengthy study and experience) but rather directly from God. The religious charismatic intuitively knows God's will both in general and in particular, and that is sufficient reason for the charismatic's pronouncements and commands. The striking -indeed at his time unparalleled-formula that Jesus used to introduce various pronouncements, "Amen I say to you," sums up this claim of the charismatic leader and (more specifically in Jesus' case) the eschatological prophet. Obviously, such a claim would not endear the charismatic to the acknowledged religious authorities, whether priestly or scribal.

It may be, then, that the only explanation for Jesus' varied statement on the Law is the very general one of the charismatic authority that he attributed to himself as the prophet sent to Israel in the end-time. Perhaps we might push this a step further: Jesus' selfpresentation to Israel as the Elijah-like prophet of the end-time may help elucidate why he dares to appropriate to himself the authority to make startling decisions about the Law, with no priestly status or formal scribal training on which to base his authority. ${ }^{14}$

However, Cardinal Koch's comments about the exchange between Pope Benedict and Rabbi Jacob Neusner suggest dissatisfaction with portraits such as Efroymson's or Meier's. Apparently, there is a desire to see the "New Testament confession of Christ" as a pre-Easter reality. Because of the church's later conflation of many christological titles and confessions, it is not clear what is meant by "Christ" here. Does it mean that before his crucifixion and resurrection Jewish

\footnotetext{
${ }^{13}$ David P. Efroymson, "Jesus: Opposition and Opponents" in David P. Efroymson, Eugene J. Fisher, and Leon Klenicki, eds., Within Context: Essays on Jews and Judaism in the New Testament (Philadelphia: American Interfaith Institute, 1993), 96. Emphases in the original; scriptural citations in the original are omitted above for convenience.

14 John P. Meier, The Marginal Jew: Rethinking the Historical Jesus. Vol. 4. Law and Love (New Haven and London: Yale University Press, 2009), 655-656. Emphasis in the original. I say "partial summary" above because I eagerly await Volume $\mathrm{V}$ of Meier's magisterial work.
} 
followers and/or Jesus himself were proclaiming him as "the anointed Messiah," or "the eschatological agent of God ushering in God's kingdom," or "one like a Son of Man coming with the clouds of heaven" [Dn 7:13], or "the incarnate Word," or "the pre-existent Son of God," etc., etc.?

Since the cardinal goes on to say that seeing the "confession of Christ" as a post-Easter development would result in a Jesus who is only a "misunderstood Jewish rabbi" (an allusion to the book by Amy-Jill Levine?) and thus remove "the real stumbling block between Judaism and Christianity," it seems that "Christ" and "divine authority" are being used in "high" christological senses, apparently meaning Jesus claiming divinity in his own being or having personal divinity attributed to his own ontological being. This would mean that contemporaneous opposition to Jesus would be based less on dismissing his claims to authoritatively act on behalf of God to condemning claims that he actually was God. Is that the "real stumbling block between Jews and Christians" the cardinal mentions? It certainly reflects post-resurrectional debates between churches and mainstream Jews (as in John 5:18), but whether it can be sustained as a real point of contention during Jesus' earthly lifetime is the crucial question.

If my inferences here are correct, several implications arise:

A. Every word in the New Testament was written in the light of faith in the one who was crucified and raised (e.g., 1 Cor 15:14,17, Lk 1:1-4; Jn 21:31). ${ }^{15}$ When discussing the historical questions of how Jesus presented himself to or was understood by Jewish contemporaries, what methodologies are employed to avoid anachronistically retrojecting back onto his ministry insights that arose with resurrection faith? ${ }^{16}$

B. The New Testament does not offer conclusive evidence that Jesus before his death claimed personal divinity or ontological divine filiation. As Raymond E. Brown wrote many years ago: "...the way in which Jesus speaks of God as Father certainly indicates that he claimed a special relationship to God. But it remains difficult to find in the Synoptic account of the public ministry an incontrovertible proof that he claimed a unique sonship that other men could not share." 17 Indeed, the fact that there is so much New Testament diversity in terms of even how the title "messiah" is employed, "would, a priori, make one think that Jesus himself did not make lucidly affirmative messianic claims during his ministry." ${ }^{18}$ How then can someone today easily assert that such claims were a critical "stumbling block" during Jesus' earthly lifetime?

\footnotetext{
${ }^{15}$ Also relevant here is the formulation of the "Three Stages of Gospel Tradition," discussed by or informing the Second Vatican Council, Dei Verbum (1965), 19; and the following studies of the Pontifical Biblical Commission: "Instruction on the Historical Truth of the Gospels" (1964), 7-10; "Instruction on the Bible and Christology" (1984), 1.2.1, 2.2.2; and "The Interpretation of the Bible in the Church" (1993), I.

${ }^{16}$ This is a very pertinent question concerning Jacob Neusner, A Rabbi Talks with Jesus: An Intermillennial, Interfaith Exchange (New York: Image Books, 1994), the volume that Pope Benedict engaged in his own book as cited by Cardinal Koch. Neusner anachronistically "dialogues" as a Talmudic rabbi, taking for granted that rabbinic teachings written only in later centuries were current in the time of Jesus, and he converses with the Matthean Jesus, without reckoning at all with Matthew's post-resurrectional creative reworking of earlier sources. See my review in New Theology Review, 9/1 (Feb, 1996): 101-103.

17 Raymond E. Brown, Jesus God and Man (New York: Macmillan, 1967), 91. Brown's comment comes while exploring the question, "How much did Jesus know?" As the latest Gospel, the Gospel of John tends to "suppress any suggestion that Jesus had to gain ordinary knowledge" (46). In fact, "the Johannine Jesus has not undergone a kenosis, i.e., taken the form of a servant. In the incarnate Jesus the glory of God's own Son constantly shines forth for all who have eyes to see" (47). That is why Brown's study focuses on the Synoptic tradition in examining claims made by and about Jesus before the crucifixion.

18 lbid., 82.
} 
C. Given the perennial deicide charge leveled by Christians down the centuries against Jews, the need to try to discern how their resurrection faith shaped the evangelists' portrayals of opposition from Jews to Jesus is of heightened importance. It is absolutely vital when considering such passages as the blasphemy accusation in Mt. 26:63-66. Did Caiaphas act against Jesus because he "blasphemously" claimed to be divine Son or because Caiaphas feared that Jesus' "blasphemous" presumptuous arrogance imperiled the survival of the Temple (cf. Jn 11: 48) $?^{19}$

D. It seems to me that imagining Jesus claimed ontological divinity during his ministry risks detaching him from his Jewish identity, thereby making his humanity unspecific and generic, and so unreal. How can God's Word be appreciated as fully incarnate if Jesus is not envisioned as one who gradually "came humanly to know" the traditions of Judaism and thus "became an authentic son of Israel, deeply rooted in his own people's long history? ${ }^{20}$ Indeed, to switch momentarily into Greek metaphysical categories, one wonders how the Chalcedonian distinction between the human and divine natures in Christ is to be maintained if Jesus is visualized as living on earth with a self-awareness of his divine Sonship that could be propositionally expressed and thus create a "stumbling block"? ${ }^{21}$

E. Finally, it is not clear to me why perceiving the divine Word as incarnate in Jesus to be postresurrectional disposes of "the real stumbling block between Christianity and Judaism." Rather, the "stumbling block" becomes the experience of the Resurrection itself. The mystery becomes why "God chose to reveal his Son" (Gal 1:15-16) to some Jews and not to others. Or why did God allow some people to experience that Jesus had "been introduced to the "world to come"'22 and others not to share in (or be inspired to be open to) that revelatory experience? Ultimately, this leads to the mysteries of Israel and the church as two interrelated but distinct co-covenanting traditions. Surely, locating the "stumbling block" in the resurrection does not eliminate the need for Catholics and Jews to dialogue! To me, it entices both of us because of our Spirit-inspired fascination with the Holy One with whom we covenant. We want to learn from each other about our experiences of God and about the divine will for our relationship with God. For instance, why has God willed to relate to our two communities in different "modes"? Is it some mistake or intended all along?

As should be clear from these ruminations, Cardinal Koch's address is a very rich survey of major topics in the Catholic-Jewish encounter and dialogue. The numerous reflections that it has triggered both for me and my colleagues in this symposium testify to its importance and insightfulness. I thank him again for his stimulating thoughts and look forward to pursuing the conversation in the future.

\footnotetext{
${ }^{19}$ See the detailed discussion of the pre- and post-resurrectional connotations of blasphemy in Raymond E. Brown, The Death of the Messiah: From Gethsemane to the Grave (New York: Doubleday, 1994), I: 520-547.

${ }^{20}$ John Paul II, "Address to the Pontifical Biblical Commission," April 11, 1997, §3.

${ }^{21}$ To repeat, Cardinal Koch has not claimed this, but it seems to me that speaking of a pre-Easter "confession of Christ" without further elaboration risks being poised on the edge of a slippery slope in this direction. No doubt there is present here a healthy tension between exegetical and dogmatic approaches to these questions, as discussed in Karl Rahner's classic essay from fifty years ago, "Dogmatic Reflections on the Knowledge and Self-Consciousness of Christ." Rahner argues that Jesus' human awareness of being directly present to God can be seen as pre-thematic or intuitive in nature, an inner-subjective mystery that possibly cannot be conceptualized in human linguistic thought constructs. [See Karl-H. Kurger, trans., Theological Investigations. Volume 5. Later Writings (Baltimore: Helicon Press, 1966), 193-215.] Rahner's point is intensified when one considers, as he really did not, that Jesus' human consciousness was a Jewish one and thus "rightly imbued with an extremely high, pure notion of the divine transcendence" [PCRRJ, "Guidelines" (1974), I].

${ }^{22}$ Pontifical Biblical Commission, "Instruction on the Bible and Christology" (1984), 1.2.6.
} 